molybdenum, were proved to be essential 'minor' elements, but progress in this field of investigation was rather slow and uncertain until techniques were developed to deal adequately with the measurement of quantities of the ordor of a few parts per million and at the same time to overcome the difficulties associated with contamination. Our ideas on 'purity' have been completely altered by innovations in micro-analytical technique such that the classical chemical methods have been largely replaced by the use of equipment that enables the analyst to carry through large numbers of determinations in a short time. Flame emission and arc methods of spectrographic analysis rapidly achieved a precision and reliability under the lead of R. L. Mitchell, and in 1948 he wrote Technical Communication No. 44 of the Commonwealth Bureau of Soils, which was a review of the literature on spectrographic analysis relevant to soils, plants and related substances, with details of the methods devised at the Macaulay Institute. This was reprinted in 1956 and now, because of continuing demand, and major advances in methods, it has been brought up to date by the provision of an addendum and appropriate bibliography occupying 37 pages (Technical Communication No. 44A, The Spectrochemical Analysis of Soils, Plants and Related Materials (with Addendum). Pp. ix+225. Farnham Royal, Bucks: Commonwealth Agricultural Bureaux, 1964. $40 s . ; 6$ dollars). The original text is still relevant and is reprinted unaltered. The introduction of directreading instruments, with "the change in emphasis" from photographic to photoelectric assessment of the spectral line intensity, "has prompted" the change in title from spectrographic to spectrochemical analysis. Some idea of the nature of the modifications of the original methods and the development of new ones may be gained from the headings of the raain sections of the addendum: the measurement of the photographic plate, direct current arc excitation, porous cup solution spark excitation, spark and interrupted arc excitation, flame photometry, atomic absorption, pretreatment of soils and plant materials, application to soil and plant investigations. The book also includes a brief description of special facilities for trace element work in the new Spectrochemistry Department of the Macaulay Institute.

\section{Soil Survey of Great Britain}

THE aim of the Agricultural Research Council Soil Survey of Great Britain is to provide a record of the soils of the country, in the form of maps and memoirs, from field observations and laboratory analyses, dosigned to establish the derivation of the soil as well as its characteristics and distribution. The printed records are of the greatest value to those concerned with agriculture or with drainage, ecology, geography or land-use. The sixteenth report (Pp. vi +39. H.M.S.O., 1964. 5s.) describes the work done in 1963; two maps show those areas of the country where field work has been completed or is in progress. For example, soil maps were published in 1963 of the districts around Cambridge and around Church Strotton, while a further nine sheets are in the press; memoirs for the district around the Menai Straits, and the aroa around Aberdeen, Inverurie and Fraserburgh have been published, and another is in the press. Several other memoirs to accompany maps are in preparation. There are brief accounts of the general pattern of the soils being mapped in various parts of Britain, of the special surveys made for such bodies as the Nature Conservancy, the National Agricultural Advisory Service, the Forestry Commission, and for various drainage authorities, and of the advice and assistance given to a wide range of enquirers. There is also a list of the contributions to scientific journals by mombers of the survey staff.

\section{International Lactic Acid Prize}

STIChtrng Ilra, International Research Association, 39 Overgaden neden Vandet, Copenhagen $K$, is offering two prizes, valued at 1,500 and 750 U.S. dollars, for the two best essays received on "The Position of Lactic Acid and its Derivatives in the Nutrition and the Metabolism of Ruminants". Entries will be assessed by an international committee of adjudicators selected by 'BIO. CENTRALEN' - the Danish Society of Biotechnical Industry and Research. All papers entered for these prizes should be submitted in English, Fronch or German to BIOCENTRALEN, Bülowsvej 13, Copenhagen $V$, not later than November 1, 1965.

\section{Perkin Centenary Trust: Awards}

Perkin Centenary scholarships for 1964 have been awarded to Mr. D. Harris, of Heaton Moor, Cheshire, tonable at the Royal College of Advanced Technology, Salford; to Mr. T. A. Moran, of Illingworth, Yorkshire, tenable at the Bradford Institute of Technology; and to Mr. J. A. Scott, of Burneside, Westmorland, tenable at the Royal College of Advanced Technology, Salford.

\section{Financing Medical Research}

THE Office of Health Economics has issued the following correction concerning the medical research expenditures of two charities which were referred to in their report The Finance of Medical Research (Nature, 203, 999; 1964). The total grants made by the Nuffield Foundation for medicine in 1961-62 amounted to $£ 669,000$, of which only $£ 245,000$ were for buildings. The Leverhulme Trust do not finance buildings at all from their funds, but do make grants for the conduct of medical research. The estimated total amount granted or allocated for the conduct of research in Britain by all trusts supporting medical research therefore amounted to approximately $£ 790,000$ in 1961. The total from all private sources was about $£ 2.5$ million, in addition to $£ 1.4$ million for buildings. The estimated total of capital and current expenditures on medical research from all sources in Britain in 1961-62 romains as $£ 27$ million.

\section{Announcements}

THE seventh British weed control conference, organized by the British Weed Control Council, will be held in Brighton during November 23-26. Further information can be obtained from Mr. W. F. P. Bishop, 140 Bensham Lane, Thornton Heath, Surrey.

A conference on "Magnetism and Magnetic Materials" will be held in Minneapolis, Minnesota, during November 16-19. Further information can be obtained from J. T. Elder, Minnesota Mining and Manufacturing Co., 400 McKnight Road, St. Paul, Minnesota 55119.

A Symposium on "Mammalian Radiobiology at tho Cellular Lovel", arranged by the British Institute of Radiology, will be held at the Institute on November 20 . Further information can be obtained from the Gonoral Secretary, British Institute of Radiology, 32 Welbeck Street, London, W.1.

THe effects on human beings of additives, colouring matter and foreign substances in foodstuffs will bo the subject of an international conference to be held in Brmo during Novomber 19-21. Further information can be obtained from Dr. M. Totová, Katedra hygieny University J. E. Purkyně, třida Obr áncủ miru 10, Brno.

A meeting of the Welsh Soils Discussion Group on "Chemical Means on Assessment of Soil Fertility" will be held at the Welsh Plant Breeding Station, Plas Gogerddan, on November 25. Further information can be obtained from Dr. A. H. Charles, Welsh Plant Breeding Station, Plas Gogerddan, near Aberystwyth. 